\title{
Quality of dried cauliflower according to the methods and drying parameters
}

\author{
Bogusława Łapczyńska-Kordon ${ }^{1}$, Barbara Krzysztofik ${ }^{2}$, Zygmunt Sobol $^{2}$ \\ ${ }^{1}$ Department of Mechanical Engineering and Agrophysicsof University of Agricultural in Krakow, Poland \\ ${ }^{2}$ Institute of Machinery Management, Ergonomics and Production Processes of University of Agricultural in Krakow, Poland
}

\begin{abstract}
The quality of food products is a complex concept. It can be defined in many ways. The common element of most of these definitions is the condition of meeting the requirements of consumers. Quality determines product compliance with the requirements set by the normalized regulations. The paper attempts to determine the optimal method and parameters of cauliflower drying. In addition, a qualitative assessment of the obtained product was made. The results show that the method and parameters of drying significantly affect the quality of the dried cauliflower. Convection drying guarantees higher drought quality with respect to the color of the sample (higher brightness), taste and odor. Of the drying parameters accepted in the experiment, the most positive effect on the tested parameters was recorded using convection drying at a flow rate of $0.2 \mathrm{~ms}^{-1}$ and the least favorable for microwave drying 170 or $210 \mathrm{~W}$.
\end{abstract}

\section{Introduction}

One of the primary ways of food preservation is drying, the reduction of the water content in the raw material. Drying improves product stability during storage and transport [1]. Drying should be carried out so as to prevent adverse changes in the products resulting in deterioration.

Selection of the appropriate drying method significantly influences the properties of the plant material such as: thermal resistance, biological and mechanical-mechanical properties, degree of fineness, and the required quality of dried food products, as well as parameters of the drying agent [2]. The choice of a suitable dryer, pre-treatment and proper process planning, as well as the knowledge of the drying kinetics of a given raw material, are the basis for obtaining a product of good quality [3].

The convection drying method is most commonly used in industry because of the simplicity of construction and easy operation of the equipment. However, the low energy efficiency of such dryers and the low quality of the resulting dried matter are the reasons for the search for methods that produce better products in terms of quality and low cost of production [4], [5]. The disadvantage of this method is the relatively long drying time and the use of high temperatures, which results in qualitative changes in the product. Thus, new technologies are being sought which would be more efficient and enable the receipt of a high quality product at minimal cost and maximum process efficiency.
The alternative method seems to be microwave energy drying, which can improve the quality of the dried product.The use of microwave drying results in better retention of aromatic components, biologically active substances and improved sensory properties of the material compared to a convection drying. Microwave heating causes intense energy release inside the material, as a result has the effect of "inflating" due to rapid evaporation of water [6]. During the process the biological material can be protected from overheating and increase the intensity of evaporation of the water by reducing the pressure inside the dryer. As a result, the drying rate is much higher than with conventional drying methods (eg convection drying). In addition, an important factor influencing the drying kinetics is the selection of the appropriate microwave power [7], [8], [9], [10].

The aim of the study was to analyze the effect of drying method and parameters on dry product quality.

The scope of work included convection and microwave-convection drying of cauliflower particles and evaluation of dry product quality in terms of color, odor, taste and shape (shrinkage).

\section{Material and method}

The subject of the study was the quality of dried cauliflower particles obtained from convection and microwave convection drying. The quality assessment included the determination of changes in sensory characteristics: odor, taste and color and shape by drying shrinkage coefficient, water content and density in dry product were also determined. 
The research was carried out on a laboratory stand for the convection drying of plant materials, designed and built at the Department of Mechanical Engineering and Agrophysics of the University of Agriculture in Krakow. The stand was equipped with: a drying chamber, in which RADWAG WPE 3000 was placed $( \pm 0.01 \mathrm{~g})$, allowing continuous measurement of mass changes during drying, heater with a maximum power of $3.04 \mathrm{~kW}$ (allowed maximum drying of the drying agent to $50^{\circ} \mathrm{C}$ ), combined with a fan. During drying, the temperature of the drying medium was measured using $\mathrm{NiCrNiAl}$ thermocouples $\left( \pm 0.1^{\circ} \mathrm{C}\right)$, at the inlet and outlet of the dryer and inside the drying chamber. Samples were dried at drying agent temperature $50^{\circ} \mathrm{C}$. The convection drying took place in a forced air dryer for three speeds: 0.1 (I); 0.2 (II); 0.3 (III) $\left[\mathrm{m}^{-} \mathrm{s}^{-1}\right.$ ]. The airflow velocity was adjusted by varying the diameter of the opening in the convection oven, the diameters being $0.07,0.12,0.17$ [m].

Microwave-convection was performed in microwave oven Moulinex - Dialog cook Y90, for three microwave power: 170, 210 and 340 [W], at air temperature $50^{\circ} \mathrm{C}$.

Cauliflower samples were cauliflower roses with an average weight of 2,2 g. In the driers the material was laid in a single layer. Samples were weighed before and after the electronic weighing of RADWAG WPE 3000 with an accuracy of $0,01 \mathrm{~g}$. During the drying were recorded the temperature and relative humidity of the drying agent. The measurement of these parameters was performed using the multifunction device company ROTRONIC.Three samples of fresh and dried material were taken to determine the density, then weighed on the RADWAG WPS 510 / c / 1 electronic scale in air and in rapeseed oil. A reading accuracy of a mass was $0,001 \mathrm{~g}$.

The color of fresh and dried material was determined on the basis of five samples each of which was photographed by a CANON digital camera. Images were analyzed for color, using MULTISCAN.

The taste and aroma were assessed using a five point scale, where 1 was the worst rating, and 5 was the best, using a expert group of evaluators (5 panelists).

The water content of the test material was calculated from the relationship:

$$
u=\frac{m p-m s}{m s}
$$

where: $\mathrm{u}$ - water content, $\left(\mathrm{kgH}_{2} \mathrm{O}(\mathrm{kgs.s})^{-1}\right)$, , $\mathrm{m}_{\mathrm{p}}$ mass of sample, $(\mathrm{kg}), \mathrm{m}_{\mathrm{s}}$ - mass of dry substance, $(\mathrm{kg})$.

The density of the tested material was determined by a method based on the Archimedes law, using a laboratory scale. The density was calculated from the formula:

$$
\rho=\frac{A}{A-B} \cdot \rho_{\mathrm{o}}
$$

where: $\rho$ - sample density $\left(\mathrm{kg} \cdot \mathrm{m}^{-3}\right), \mathrm{A}$ - mass of sample in air $(\mathrm{kg}), \mathrm{B}$ - mass ofsample in oil $(\mathrm{kg}), \rho_{\mathrm{o}}$ density of oil $\left(\mathrm{kg} \cdot \mathrm{m}^{-3}\right)$.
Drying shrinkage was calculated from the relationship:

$$
s_{k}=\left(\frac{A_{p}}{A_{s}}\right)^{\frac{3}{2}} \cdot 100 \%
$$

where: $s_{k}$ - drying shrinkage $(\%), A_{p}$ - sample area $\left(\mathrm{mm}^{2}\right), A_{\dot{s}}$ - average area of freshmaterial $\left(\mathrm{mm}^{2}\right)$.

Each measurement was performed in triplicate. The results of the measurements were subjected to a basic statistical analysis.

Mean and standard deviations were calculated and variance analysis was performed with Duncan's test for dependence between dependent and independent variables. In addition, Pearson's linear correlation analysis was performed for dependent variables. For all statistical calculations the significance level $\alpha=0.05$ was assumed.

\section{Results and analysis}

The obtained results of studies on density changes, drying shrinkage, taste and odor and water content and color of dried products, depending on the method and conditions of drying, are presented in the form of figures and tables as mean values with standard deviations. The average density of fresh material varied from $0.961 \mathrm{~kg} \cdot \mathrm{m}^{-3}$ (for microwave-convection drying at $210 \mathrm{~W}$ ) to $1.101 \mathrm{~kg} \cdot \mathrm{m}^{-3}$ (for sample III for convection drying at an air flow rate of $0.3 \mathrm{~m} \mathrm{~s}^{-1}$, for which the highest standard deviation was recorded, ie: 0.097). The remaining deviations from the mean were low, ie: 0.002-0.007 (Figure 1). The highest increase density of simple of the dry material compared to the fresh sample was recorded for convection drying at an air flow rate of $0.3 \mathrm{~ms}^{-1}$ (III). The recorded growth was $20.9 \%$. After microwave drying at 210 and $340 \mathrm{~W}$ and conventional drying at a flow rate of $0,2 \mathrm{~ms}^{-1}$ (II), the density of dried material relative to fresh material was reduced. 


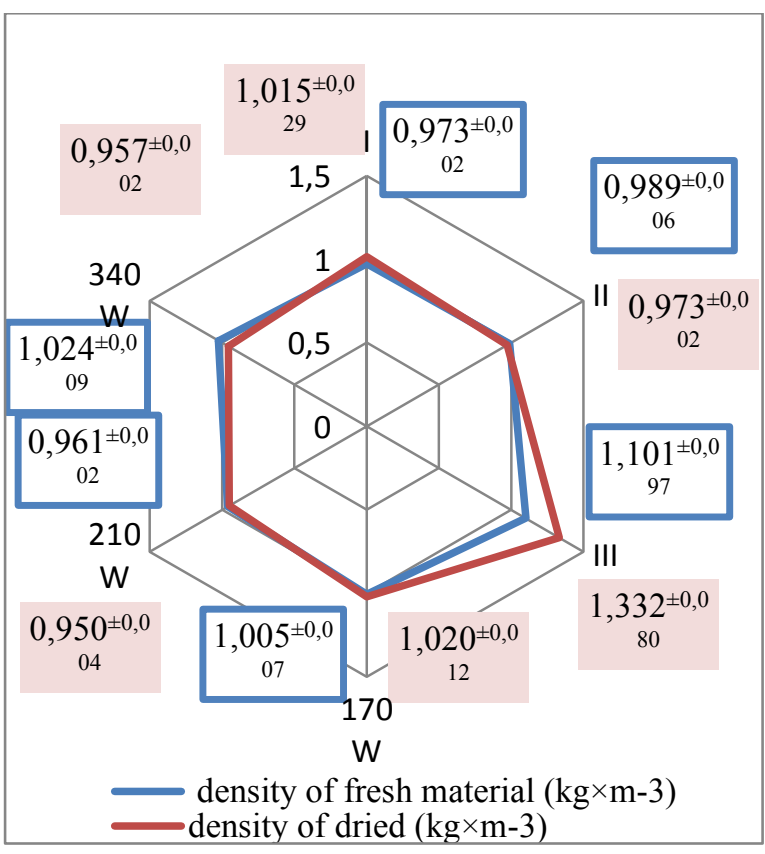

Fig. 1. The density of the samples before and after drying

The greatest decrease in the density of $(6.6 \%)$ was observed for the material after drying with a microwave power of $340 \mathrm{~W}$.

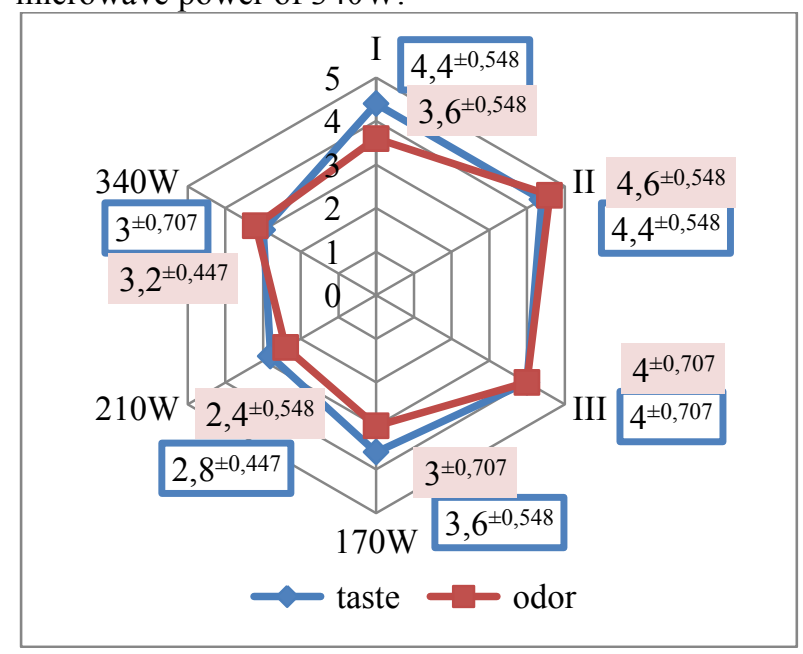

Fig. 2. Results of organoleptic evaluation for taste and odor

Significant statistically differentiation has been found to evaluate the taste and odor of dry products obtained by various drying methods. The higher tasting values on the 5-step scale obtained the drought obtained from the conventional drying method (4-4) (Figure 2). The highest value was obtained with an air flow rate of $0.2 \mathrm{~m} \cdot \mathrm{s}^{-1}$ (II). For microwave- convection drying its value was in the range of 2.8 for drying at $210 \mathrm{~W}$ to 3.6 for $170 \mathrm{~W}$. Similarly, when evaluating the taste, odor evaluation results are formed. Significantly higher values in the sensory evaluation were obtained by conventional methods compared to microwaveconvection. Similarly, when evaluating the taste, odor evaluation results are formed. Significantly higher values in the sensory evaluation dried samples obtained by the convection method in comparison with the microwave - convection.
The highest value of drying shrinkage was recorded at air velocity of $0,2 \mathrm{~ms}^{-1}$ (II), respectively 4.6 points, lowest at $210 \mathrm{~W}$ microwave power, 2.4 points respectively. Methods and parameters of a drying affected drying shrinkage and water content significantly (Table 2). The highest values of water content were recorded for dry products obtained from convection drying at air flow velocities of 0,2 and 0.3 $\mathrm{ms}^{-1}$ (II and III), respectively 8.05 and $6.43 \mathrm{~kg}$ $\mathrm{H}_{2} \mathrm{O} \cdot$ kgs.s. $^{-1}$ (Figure 3). The lowest water content was recorded in microwave drying at 210 and $170 \mathrm{~W}$ microwave power, respectively 1,53 and $3,41 \mathrm{~kg}$ $\mathrm{H}_{2} \mathrm{O}(\text { kgs.s })^{-1}$.

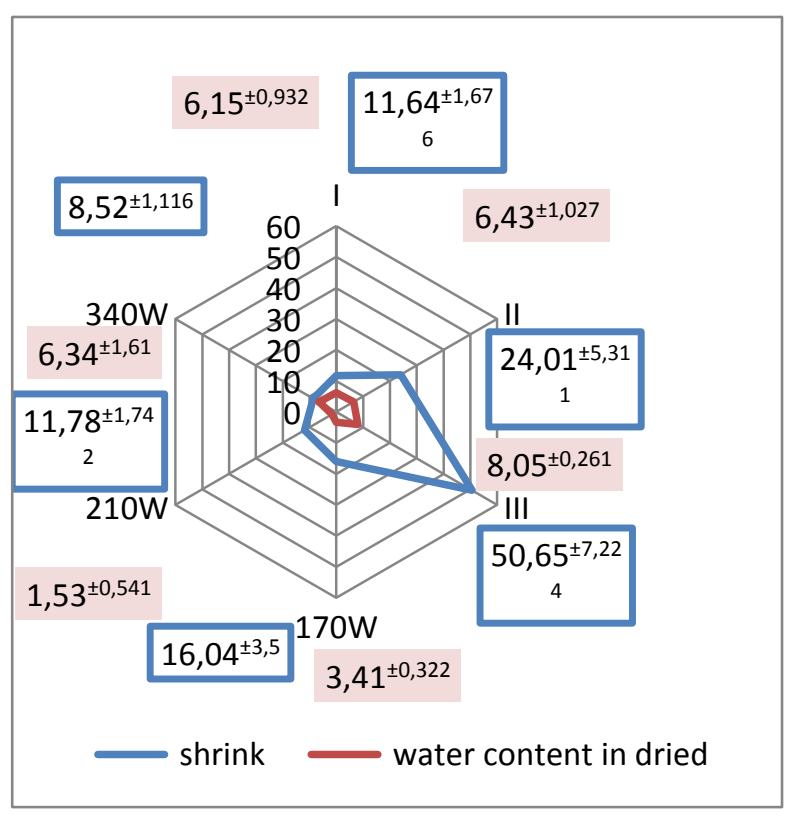

Fig. 3. The water content of dried material $\left(\mathrm{kg} \mathrm{H}_{2} \mathrm{Okgss}^{-1}\right)$, and drying shrinkage (\%)

Analysis of drying shrinkage of samples indicates significant differences between drying methods (Table 2 ). The highest value of the shrinkage was observed for the sample dried convection method using air flow rate of 0.3 and $0.2 \mathrm{~m} \cdot \mathrm{s}^{-1}$, respectively, 50.65 and $24.01 \%$. The highest shrinkage value was recorded for samples with a microwave power of $340 \mathrm{~W}$.

Evaluation of color parameters showed that samples before and after drying were significantly different. Compared to the fresh sample, higher sample brightness was observed for convection drying at an air flow rate of $0,2 \mathrm{~ms}^{-1}$ (II). On the other hand, it was significantly lower for the dried food obtained from the microwave oven at $170 \mathrm{~W}$, for which all other color parameters were also the lowest. Compared to the fresh sample, higher $\mathrm{r}, \mathrm{b}$ and $\mathrm{y}$ parameters were recorded for most drying methods, while the lower values for parameter g (Table 1).

The analysis of the correlation between the dependent variables (Table 3) showed a significant positive correlation between the water content in the dried material and drying shrinkage, density of a sample of fresh and dried. With the density of the fresh sample, the drying shrinkage and the ' $\mathrm{g}$ ' parameter and the density of the dried were significantly correlated. 
Drying shrinkage, water content, color g parameter and dry material density.

negative ' $r$ ' color are significantly correlated with the

Table 1. Parameters of the color of fresh material and dried.

\begin{tabular}{|l|c|c|c|c|c|}
\hline \multirow{2}{*}{$\begin{array}{l}\text { Sample of fresh } \\
\text { material }\end{array}$} & Average rightness & $\mathrm{r}$ & $\mathrm{b}$ & $\mathrm{g}$ & $\mathrm{y}$ \\
\cline { 2 - 6 } & $254.73^{ \pm 0.20}$ & $220.46^{ \pm 0.82}$ & $214.11^{ \pm 2.94}$ & $196.40^{ \pm 6.23}$ & $213.49^{ \pm 3.25}$ \\
\hline I & $254.08^{ \pm 0.10}$ & $234.71^{ \pm 0.81}$ & $221.90^{ \pm 3.10}$ & $183.85^{ \pm 7.57}$ & $221.07^{ \pm 2.85}$ \\
\hline II & $254.86^{ \pm 0.24}$ & $228.86^{ \pm 5.15}$ & $221.27^{ \pm 589}$ & $188.51^{ \pm 6.67}$ & $219.40^{ \pm 5.74}$ \\
\hline III & $254.71^{ \pm 0.30}$ & $223.71^{ \pm 1.47}$ & $220.65^{ \pm 1.65}$ & $196.68^{ \pm 1.61}$ & $218.33^{ \pm 1.54}$ \\
\hline $170 \mathrm{~W}$ & $252.49^{ \pm 1.25}$ & $220.90^{ \pm 1.75}$ & $211.74^{ \pm 2.59}$ & $171.79^{ \pm 4.35}$ & $209.55^{ \pm 2.42}$ \\
\hline $210 \mathrm{~W}$ & $254.08^{ \pm 0.10}$ & $234.71^{ \pm 0.81}$ & $221,90^{ \pm 3.10}$ & $183.85^{ \pm 7.57}$ & $221.07^{ \pm 2.85}$ \\
\hline $340 \mathrm{~W}$ & $254.06^{ \pm 0.21}$ & $235.23^{ \pm 0.52}$ & $223.21^{ \pm 2.01}$ & $186.57^{ \pm 5.11}$ & $222.29^{ \pm 1.76}$ \\
\hline
\end{tabular}

Table 2. Results of Duncan test - of one-dimensional significance tests for the parameters tested.

\begin{tabular}{|c|c|c|c|c|c|}
\hline \multirow{3}{*}{ Effect } & \multicolumn{4}{|c|}{ Differences between the test samples } & \multirow{3}{*}{$\begin{array}{c}\text { Duncan's test results } \\
\text { for I-340 }\end{array}$} \\
\hline & \multicolumn{2}{|c|}{$\begin{array}{l}\text { Convection and microwave- } \\
\text { convection }\end{array}$} & \multicolumn{2}{|l|}{$\mathrm{I}-340 \mathrm{~W}$} & \\
\hline & $\mathrm{F}$ & $\mathrm{p}$ & $\mathrm{F}$ & $\mathrm{p}$ & \\
\hline \multicolumn{6}{|c|}{ Drying_shrinkage } \\
\hline $\begin{array}{l}\text { Constant } \\
\text { parameter }\end{array}$ & 77.709 & $\mathbf{0 . 0 0 0}$ & 754.012 & 0.000 & \multirow[t]{2}{*}{$\begin{array}{l}\text { I - 170W, 210W, 340W; } \\
210 \mathrm{~W}-170 \mathrm{~W}, 340 \mathrm{~W} ;\end{array}$} \\
\hline Combinations & 12.895 & 0.001 & 74.561 & 0.000 & \\
\hline \multicolumn{6}{|c|}{ Moisture_content } \\
\hline $\begin{array}{l}\text { Constant } \\
\text { parameter }\end{array}$ & 266.192 & $\mathbf{0 . 0 0 0}$ & 1022.725 & 0.000 & \multirow[t]{2}{*}{$\begin{array}{l}\text { I - II, 340W; } \\
\text { II - 340W; }\end{array}$} \\
\hline Combinations & 22828 & $\mathbf{0 . 0 0 0}$ & 34.257 & $\mathbf{0 . 0 0 0}$ & \\
\hline \multicolumn{6}{|c|}{ taste } \\
\hline $\begin{array}{l}\text { Constant } \\
\text { parameter }\end{array}$ & 1078.088 & $\mathbf{0 . 0 0 0}$ & 1173.429 & $\mathbf{0 . 0 0 0}$ & \multirow{2}{*}{$\begin{array}{l}\text { I - II, III, 170W; } \\
\text { II - III, 170W; } \\
\text { III - 170W; } \\
170 \mathrm{~W}-210 \mathrm{~W}, 340 \mathrm{~W} ; \\
210 \mathrm{~W}-340 \mathrm{~W} ;\end{array}$} \\
\hline Combinations & 25.288 & $\mathbf{0 . 0 0 0}$ & 6.800 & 0.000 & \\
\hline \multicolumn{6}{|c|}{ smell } \\
\hline $\begin{array}{l}\text { Constant } \\
\text { parameter }\end{array}$ & 796.968 & $\mathbf{0 . 0 0 0}$ & 1030.095 & $\mathbf{0 . 0 0 0}$ & \multirow{2}{*}{$\begin{array}{l}\text { I -III, 170W; } \\
\text { II - III; } \\
\text { 170W - 210W; } \\
\text { 340W - I, III, 170W, 210W; }\end{array}$} \\
\hline Combinations & 23874 & 0.000 & 8.610 & 0.000 & \\
\hline \multicolumn{6}{|c|}{ Average_brightness } \\
\hline $\begin{array}{l}\text { Constantparam } \\
\text { eter }\end{array}$ & 3154248.581 & $\mathbf{0 . 0 0 0}$ & 6534237.131 & 0.000 & \multirow{2}{*}{$\begin{array}{l}\text { I - III, 210W, 340W; } \\
\text { II - III; } \\
\text { III- } 210 \mathrm{~W}, 340 \mathrm{~W} ; \\
210 \mathrm{~W}-340 \mathrm{~W}\end{array}$} \\
\hline Combinations & 12.436 & 0.001 & 11.953 & 0.000 & \\
\hline \multicolumn{6}{|c|}{$\mathbf{r}$} \\
\hline $\begin{array}{l}\text { Constantparam } \\
\text { eter }\end{array}$ & 40404.915 & 0.000 & 284639.927 & 0.000 & \multirow{2}{*}{$\begin{array}{l}\text { I - 210W, } 340 \mathrm{~W} \\
\text { III - } 170 \mathrm{~W} \\
210 \mathrm{~W}-340 \mathrm{~W}\end{array}$} \\
\hline Combinations & 0.270 & 0.607 & 35.031 & 0.000 & \\
\hline \multicolumn{6}{|c|}{ b } \\
\hline $\begin{array}{l}\text { Constantparam } \\
\text { eter }\end{array}$ & 60986.804 & 0.000 & 129485.267 & 0.000 & \multirow{2}{*}{$\begin{array}{l}\text { I - II, III, } 210 \mathrm{~W}, 340 \mathrm{~W} ; \\
\text { II -III, } 210 \mathrm{~W}, 340 \mathrm{~W} \\
\text { III - 210W, } 340 \mathrm{~W} ; \\
210 \mathrm{~W}-340 \mathrm{~W}\end{array}$} \\
\hline Combinations & 1.704 & 0.202 & 7.813 & 0.000 & \\
\hline \multicolumn{6}{|c|}{$\mathbf{g}$} \\
\hline $\begin{array}{l}\text { Constantparam } \\
\text { eter }\end{array}$ & 15423.173 & 0.000 & 29865.216 & 0.000 & \multirow{2}{*}{$\begin{array}{l}\text { I - II, 210W, 340W; } \\
\text { II - 210W, 340W; } \\
210 \mathrm{~W}-340 \mathrm{~W}\end{array}$} \\
\hline Combinations & 8.989 & 0.006 & 9.525 & 0.000 & \\
\hline
\end{tabular}




\begin{tabular}{|l|r|r|r|r|l|}
\hline \multicolumn{9}{|c|}{ y } \\
\hline $\begin{array}{l}\text { Constantparam } \\
\text { eter }\end{array}$ & 53178.646 & 0.000 & 142184.619 & $\mathbf{0 . 0 0 0}$ & $\begin{array}{l}\text { I - II, III, 210W, 340W; } \\
\text { II - III, 210W, 340W; }\end{array}$ \\
\cline { 1 - 3 } Combinations & 1.071 & 0.310 & 10.746 & $\mathbf{0 . 0 0 0}$ & $\begin{array}{l}\text { III - 210W, 340W; } \\
\text { 210W - 340W; }\end{array}$ \\
\hline
\end{tabular}

The bolds were marked by significant relationships at $\alpha=0.05$

Table 3. Results of linear correlation analysis for dependent variables.

\begin{tabular}{|c|c|c|c|c|c|c|c|c|c|c|}
\hline $\begin{array}{l}\text { Dependent } \\
\text { variables }\end{array}$ & $\begin{array}{c}\text { Drying } \\
\text { shrinkage } \\
(\%)\end{array}$ & $\begin{array}{c}\text { Moisture } \\
\text { content }(\mathrm{kg} \\
\left.\mathrm{H}_{2} \mathrm{O} \cdot \mathrm{kg}_{\mathrm{ss}}^{-1}\right)\end{array}$ & $\begin{array}{c}\text { Taste } \\
(-)\end{array}$ & $\begin{array}{c}\text { Odor } \\
(-)\end{array}$ & $\begin{array}{c}\text { Average } \\
\text { bright- } \\
\text { ness }\end{array}$ & $\mathrm{r}$ & $\mathrm{b}$ & $\mathrm{g}$ & $\mathrm{y}$ & $\begin{array}{l}\text { Density } \\
\text { of fresh } \\
\text { sample } \\
\left(\mathrm{kg} \cdot \mathrm{m}^{-3}\right)\end{array}$ \\
\hline $\begin{array}{l}\text { Moisture } \\
\text { content in dried } \\
\left(\mathrm{kg} \mathrm{H}_{2} \mathrm{O} \cdot \mathrm{kgss}^{-1}\right)\end{array}$ & 0.620 & & & & & & & & & \\
\hline Taste(-) & 0.383 & 0.635 & & & & & & & & \\
\hline Odor & 0.371 & 0.566 & 0.541 & & & & & & & \\
\hline $\begin{array}{l}\text { Average } \\
\text { brightness }\end{array}$ & 0.377 & 0.434 & 0.417 & 0.522 & & & & & & \\
\hline $\mathrm{r}$ & -0.665 & -0.274 & -0.105 & -0.149 & 0.346 & & & & & \\
\hline $\mathrm{b}$ & -0.138 & 0.179 & 0.149 & 0.167 & 0.644 & 0.748 & & & & \\
\hline g & $\mathbf{0 . 6 3 7}$ & 0.625 & 0.344 & 0.491 & 0.674 & -0.049 & 0.602 & & & \\
\hline $\mathrm{y}$ & -0.240 & 0.100 & 0.102 & 0.122 & 0.633 & 0.834 & 0.988 & 0.502 & & \\
\hline $\begin{array}{l}\text { Density of } \\
\text { moist material } \\
\left(\mathrm{kg} \cdot \mathrm{m}^{-3}\right)\end{array}$ & 0.648 & 0.559 & 0.121 & 0.065 & 0.160 & -0.404 & 0.059 & 0.566 & 0.034 & \\
\hline $\begin{array}{l}\text { Density of } \\
\text { dried material } \\
\left(\mathrm{kg} \cdot \mathrm{m}^{-3}\right)\end{array}$ & 0.876 & 0.647 & 0.303 & 0.111 & 0.257 & -0.528 & -0.024 & 0.637 & 0.118 & 0.804 \\
\hline
\end{tabular}

\section{Conclusions}

Analysis of the results allowed to draw the following conclusions:

1. The method and parameters of drying significantly affect the quality of the dried cauliflowers obtained.

2. Convection drying guarantees higher quality of the dried cauliflowers with respect to the color of the sample (higher luminosity), taste and odor.

3. Of the drying parameters accepted in the experiment, the most positive effect on the tested parameters was recorded using convection drying at a flow rate of $0.2 \mathrm{~m} \cdot \mathrm{s}^{-1}$ and the least favorable for microwave drying 170 or $210 \mathrm{~W}$.

4. Significant positive correlation was found between density of dried and moist sample, water content and drying shrinkage.

\section{References}

1. B. Krzysztofik, T. Dróżdż, Z. Sobol, P. Nawara, P. Wrona,. Methods of securing and preserving raw materials and food products(Monograph. Ed. Agric. Eng. ISBN 978-83-64377-14-3 (2015)
2. B. Bijok, F. Bijok, A. Dąbek,. Raw materials and food technology, Part II. (Surowce I technologia żywności część II). WSiP(2001)

3. E. Biller, A. Wierzbicka, A. Półtorak, Agric.Eng. 9(69) (2005)

4. D. Witrowa-Rajchert, Rehydration as an indicator of changes occurring in plant tissue during drying. (Habilitation dissertation Ed. SGGW in Warszawa)) 29. ISBN 83-87660-95-7 (1999)

5. M. Rząca, D. Witrowa- Rajchert, Acta Agrophys. 9(2), (2007)

6. J. Oszmiański, Technology and analysis of fruit and vegetable products. Selected Issues.(Ed. of Wrocław University of Environmental and Life Sciences (2002)

7. A. Andres, K. Bilbao, P. Fito, J. of Food Eng. 63. (2004)

8. M. Szarycz, E. Kamiński, K. Jałoszyński, A. Szponarska, Acta Sci. Pol.Technika_Agraria 2(2). (2003)

9. A. Marzec, M. Zadrożna, ActaAgrophys.12(2) (2008)

10. T. M. Lin, T. D. Durance, C. N. Scaman, Food Res. Inter. 31 (2) (1998) 